\title{
Triptolide: Regulator of Cellular Metabolism of Significant Fraction of Small Cell Lung Cancer via lncRNAs
}

\section{Triptolit: Küçük Hücreli Akciğer Kanserinin Önemli Fraksiyonunun lncRNA 'lar aracılı Hücresel Metabolizmasının Düzenleyicisi}

\author{
Onur Tokgün $^{1} \mathbb{D}$, Kubilay İnci² ${ }^{2}$
}

${ }^{1}$ Pamukkale University, Faculty of Medicine, Medical Genetics, Denizli, Turkey

2 Pamukkale University, Institute of Medical Sciences, Department of Cancer Molecular Biology, Denizli, Turkey

ORCID: O.T. 0000-0003-0537-9032; K.İ. 0000-0001-9341-7945

Corresponding author/Sorumlu yazar: Onur Tokgün,

Pamukkale University, Faculty of Medicine, Medical Genetics, Denizli, Turkey

E-mail: otokgun@pau.edu.tr

Submitted/Geliş tarihi: 19.05.2021 First Revision Received/İlk revizyon: 27.05.2021 Last Revision Received/Son Revizyon: 27.05.2021 Accepted/Kabul Tarihi: 11.06.2021

Citation/Atıf: Tokgun O, Inci K. Triptolide: regulator of cellular metabolism of significant fraction of small cell lung cancer via lncRNAs. Sağlık Bilimlerinde İleri Araştırmalar Dergisi 2021; 4(3): 95-103.

https://doi.org/10.26650/JARHS2021-939378

\section{ABSTRACT}

Objective: Small cell lung cancer accounts for $15 \%$ of all lung cancer cases. Myc family is frequently amplified and/or overexpressed in $20 \%$ of small cell lung cancers and can promote carcinogenesis. Triptolide, a Chinese medicinal herb, is an anticancer reagent isolated from Tripterygium wilfordii Hook $\mathrm{f}$. This study aimed to investigate Triptolide's possible effect on Myc overexpressed/ amplified SCLC cells.

Materials and methods: To determine the expression of Myc and Myc-dependent metabolic genes, H209, H209myc, N417, and Lu135 cells were treated with Triptolide, and expression levels of Myc and associated lncRNAs were measured by qRT-PCR. Western blot analysis was performed to evaluate Myc, p21, cyclin D1 expressions. Besides, glucose uptake activity was assessed in the triptolide-treated cells.

Results: We have observed that Triptolide inhibited the proliferation of SCLC cells by inhibiting MYC expression. Triptolide has been found to repress cellular proliferation, glucose metabolism, and glucose uptake, resulting in decreased Glut1, Glut4, HK2, LDHA, and Eno1. Triptolide changed the expressions of cellular proliferation and metabolism-related lncRNAs (ANRIL, PVT1, PTENP1, H19, and lincRNA-p21).

Conclusion: The results have strongly indicated that triptolide treatment reduces cellular proliferation and glucose metabolism by regulating lncRNA expressions. Triptolide treatment would be a promising therapeutic strategy for SCLC.

Keywords: Triptolide, Small cell lung cancer, MYC, lncRNA, Metabolism

öz

Amaç: Küçük hücreli akciğer kanseri (KHAK), tüm akciğer kanseri vakalarının \%15'ini oluşturmaktadır. Myc ailesi, küçük hücreli akciğer kanserlerinin \%20'sinde sıklıkla amplifiye/ aşırı eksprese edilir ve karsinogenezi indüklemektedir. Bir Çin şifalı bitkisi olan Triptolit, Tripterygium wilfordii Hook f'den izole edilen bir antikanser moleküldür. Bu çalışma, Triptolit'in Myc aşırı eksprese/amplifiye KHAK hücreleri üzerindeki olası etkisini araştırmayı amaçlamıştır.

Materyal ve metod: Myc ve Myc'ye bağlı metabolik genlerin ekspresyonunu belirlemek için H209, H209myc, N417 ve Lu135 hücreleri Triptolit ile muamele edildi ve Myc ve ilişkili lncRNA'ların ekspresyon seviyeleri qRT-PCR ile analiz edildi. Myc, p21, siklin D1 protein ifadelerini değerlendirmek için Western blot analizi yapıldı. Ayrıca, triptolit ile muamele edilmiş hücrelerde glikoz alınım aktivitesi ölçüldü.

Bulgular: Triptolit'in MYC ekspresyonunu inhibe ederek KHAK hücrelerinin proliferasyonunu baskıladığını gözlemledik. Triptolitin hücresel proliferasyonu, glikoz metabolizmasını ve glikoz alımını inhibe ettiği ve Glut1, Glut4, HK2, LDHA ve Eno1 ifadelerinde azalmaya neden olduğu saptandı. Triptolit'in hücresel proliferasyon ve metabolizma ile ilişkili lncRNA'ların (ANRIL, PVT1, PTENP1, H19 ve lincRNA-p21) ifadelerini düzenlediği gözlemlendi.

Sonuç: Sonuçlar, triptolit tedavisinin lncRNA ekspresyonlarını düzenleyerek hücresel proliferasyonu ve glikoz metabolizmasını baskıladığını güçlü bir şekilde göstermiştir. Triptolit tedavisinin KHAK için umut verici bir terapötik strateji olacağını düşünmekteyiz. Anahtar Kelimeler: Triptolit, Küçük hücreli akciğer kanseri, MYC, lncRNA, Metabolizma 


\section{INTRODUCTION}

Small cell lung cancer (SCLC) is one of the subtypes of neuroendocrine tumors and accounts for $15 \%$ of all lung cancer cases (1). Disruption of essential tumor suppressor genes such as RB1, Tp53, and PTEN, rapid doubling time and development of chemoresistance, metastasis to distant cities, and poor prognosis are the characteristic features of SCLC $(1,2)$. SCLC differs from other lung cancer types in morphological, histological, and genetic characteristics (3). SCLC is classified into two subtypes as limited and extensive-stages, and a majority of patients with SCLC are diagnosed with extensive-stage and metastatic findings in diagnosis. One-year survival and five-year survival rates are $40 \%$ and 5\%, respectively, and most patients have smoking histories (4). Therapeutic options are determined according to the disease stage, but traditional therapies comprising combination platinum-based chemotherapy are insufficient $(3,5)$.

In vitro and in vivo studies revealed that Ascl1, NeuroD1, SOX2, and Myc family members are driver transcription factors that conduct the genetic composition of cells that constitute tumoral structure in the SCLC (6). Aberrant transcriptional activity of these transcription factors can regulate cellular processes, including proliferation, apoptosis, cell cycle regulation, chemoresistance, differentiation, survival changes. Recent molecular studies revealed that at least one member of the Myc family is frequently amplified and/or overexpressed in 20\% of SCLCs. Genomic profiling studies reported that Myc regulates $15 \%$ of the whole genome roughly (7). Myc is the transcription factor that can promote carcinogenesis as a result of oncogenic activation by regulating the expression of specific genes that play essential roles in cell growth (8), cell cycle (9), apoptosis $(10,11)$, energy metabolism (12), DNA replication (8), etc. Therefore, Myc is defined as one of the SCLC targets, and any drugs developed against Myc can block tumor progression (13).

Malignant cells are characterized by abnormal metabolic programming and over-energy production. Cellular metabolism and proliferation are closely linked to cellular processes. Myc activates metabolismrelated genes by binding to their conserved E-box sites. Accumulative pieces of evidence have demonstrated that Myc directly regulates the expressions of exclusive glycolytic genes involving SLC2A1, HK2, ENO1, LDHA $(14,15)$. On the other hand, Myc can indirectly regulate cancer metabolism through non-coding RNAs such as lncRNAs (16). Myc-regulated lncRNAs play roles in various metabolic pathways like glucose uptake and glycolysis/ gluconeogenesis (17). Accordingly, Myc is a crucial target as a therapeutic target because of regulating different aspects of cancer cell metabolism. In various levels as transcription, mRNA maturation and stability, translation, post-translational modification, and protein-protein interaction, Myc is targetable by different molecules to treat SCLC

$(17,18)$. Kato et al. showed that JQ1 inhibits SCLC cell growth by repressing Myc expression (19). Moreover, Fiorentino et al. demonstrated that Omomyc could reduce MYC's ability to bind MYC target genes' promoters by disturbing interaction with Max (20). Although multiple molecularly targeted agents have been assessed in SCLC with limited success in patient clinical outcomes, recently, Myc targeted therapy strategies could be successful.

Triptolide is the anticancer reagent isolated from Tripterygium wilfordii Hook f (TWHf), a Chinese medicinal herb $(21,22)$. It has crucial properties as immunomodulatory and antitumor effects as well as pharmacological activities. On the other hand, Triptolide does regulate not only oncogenes but also tumor suppressor genes. It increases the expression of p21, leading to cell cycle arrest, and induces DNA damage despite reducing cyclin family members' expression, including cyclin A, B, C, D $(23,24)$. In the literature, it has been reported that Triptolide suppresses the cellular proliferation of pancreatic cancer by regulating c-Myc expression. However, there is no report showing the effect and mechanism of Triptolide on SCLC in the literature. For this reason, in this study, we aimed to investigate Triptolide's possible effect on Myc overexpressed/ amplified SCLC cells. 


\section{MATERIALS AND METHODS}

\section{Cell Culture}

Human small cell lung cancer cell lines (H209, N417, and Lu135) were obtained from Dr. Jun Yokota. Myc status of the cell lines used in the study; H82 and N417 cell lines carrying MYC amplification and H209 cells with very low expression of MYC (13). Cell lines were cultured in RPMI-1640 medium, including 10\% fetal bovine serum (FBS)(Capricorn, South America), $1 \%$ penicillin/ streptomycin (Gibco by Life Technologies, USA) at $37^{\circ} \mathrm{C}$ with $5 \% \mathrm{CO}_{2}$.

\section{Generation of Myc overexpression by lentiviral Myc expression vector}

H209 cells are characterized by growing in floating aggregates, expressing neuroendocrine markers and not expressing c-Myc (25). Therefore, for the overexpression of Myc, H209 cells were infected with the $\mathrm{pCDH}-\mathrm{Myc}$ vector which is generated by ourselves. $\mathrm{pCDH}-\mathrm{Myc}$ vector has the strong CMV promoter upstream of an MCS and provides stable Myc expression. We named the infected H209 cells H209myc and H209, respectively. H209 cells were cultured in T25 flasks with $5 \mathrm{ml}$ of medium. Cells were infected with a combination of lentivirus and Polybrene (Sigma Aldrich, Germany). 24hrs after infection, cells were washed with PBS twice and cultured with RPMI140 medium supplemented with FBS (Sigma, USA). H209 cells were grown for approximately five days. To select the stably infected cells, the cells were then treated with G418 (400 $\mu \mathrm{g} /$ $\mathrm{ml}$ ) (Sigma, USA) for at least two passages to maintain optimal plasmid integration. After the infection step, Myc expression status was evaluated by Western blot analysis.

\section{Cell Viability Assay}

Triptolide was purchased from Aktin Laboratories (cat: SPC-305, PRC. ). H209, H209myc, N417, and Lu135 cells were seeded in a 96-well plate (Corning) at a concentration of $1,5 \times 10^{4} \mathrm{cell} /$ well. Cells were incubated at $37^{\circ} \mathrm{C}$ in a $5 \% \mathrm{CO} 2$ incubator. After $24 \mathrm{hrs}$, cells were treated with Triptolide which was added to the medium in different concentrations $(0,1,5,10,25,50,100 \mathrm{ng} / \mathrm{ml})$ for $24 \mathrm{hrs}$. Its control groups were not treated with Triptolide. At the end of incubation periods, Abbkine cell counting kit-8 (China) was used to determine cell viability. The protocol was performed according to the manufacturer's instructions.

\section{RNA Isolations, cDNA synthesis, and qRT- PCR Assay}

To determine the expression of Myc and Mycdependent metabolic genes in SCLC cell lines, N417 and Lu135 cells (non-treated, controls groups) and its counterpart treated with Triptolide were isolated using TRIzol LS Reagent (Invitrogen, USA) and RNeasy Mini Kit (Qiagen, Germany) according to the manufacturer's instructions. To determine quality, RNA samples were measured by means of OD260/280 using a NanoDrop ND-1000 instrument. cDNAs from total RNA samples were synthesized using a Reverse Transcription Kit ( miScript II RT kit, Q1agen). Expression levels of Myc and associated genes (ANRIL, PVT1, H19, PTENP1, and LINCRNAp21) were measured by qRT-PCR using a QuantiTect SYBR Green PCR Kit. GAPDH was used as the internal control, and the transcription levels of relative genes were calculated using the $2^{\wedge}$-DDCt method.

\section{Western blotting analysis}

Cells were lysed with ice-cold RIPA buffer $(50 \mathrm{mM}$ TRIS, $0.5 \%$ sodium deoxycholate, $1.0 \%$ NP-40, $0.1 \%$ SDS, $150 \mathrm{mM} \mathrm{NaCl}, 2 \mathrm{mM}$ EDTA) including phosphatase and protease inhibitors (Roche). Equal amounts $(30 \mu \mathrm{g})$ of protein lysates were run to separate sodium dodecyl sulfate-polyacrylamide gels. After separation, nonspecific bindings were blocked in BSA solution for two h. Following, protein samples were probed with primer antibody anti-human c-Myc (sc40, Santa Cruz, USA), (p21, Cyclin D1) (Cell Signaling Technology, Danvers, MA, USA), and a-tubulin (CP06, CalBiochemicals, USA). Membranes were then incubated with a peroxidase-conjugated secondary antibody at room temperature. The bands were scanned with Odyssey ${ }^{\circledR}$ Fc Imaging System (LICOR Biosciences). The band intensities were quantified by densitometric analysis using Image Studio Lite Ver 5.0. For each sample, the values of the 
band were firstly normalized with band values of its a-tubulin. Subsequently, fold change calculated by its control group. The band intensities were quantified by using the ImageJ gel analysis program.

\section{Glucose Uptake Assay}

A Glucose Uptake-Glo ${ }^{\text {tm }}$ Assay kit (Promega, USA) was used to measure glucose uptake activity in the cells. Human SCLC cells, N417 and Lu135, were seeded into a 6 -well plate $\left(1 \times 10^{5}\right.$ cells/well). Briefly, cells were treated with triptolide $24 \mathrm{hrs}$ after incubation. 2 days later, the medium was removed, and cells were then washed twice in PBS following the manufacturer's instructions. To initiate glucose uptake, $50 \mu \mathrm{l}$ of the $1 \mathrm{mM} 2 \mathrm{DG}$ in PBS was added per well and incubated for 10 minutes at room temperature. The uptake reaction was stopped by adding $25 \mu$ of Stop Buffer. The samples were processed as a regular protocol by adding $25 \mu$ of Neutralization Buffer, and $100 \mu \mathrm{l}$ 2DG6P Detection Reagent followed by incubation for 5 hours at room temperature. Luciferase activity was determined using a Promega GloMax ${ }^{\circledast}$ instrument.
The non-treated counterpart of cells was used as the control group when statistically analyzed.

\section{Statistical analysis}

All experiments were performed in triplicates and repeated independently to confirm the results. Data analysis of gene expression was performed using Excel-based PCR Array Data Analysis Software provided by the Qiagen company. Significance was determined with $p$ values of $\leq 0.05$.

\section{RESULTS}

Expression of Myc in pCDH-Myc Vectors Infected in $\mathrm{H} 209$ Cells

To validate if selected colonies express Myc, the lentiviral infection was performed in H209, MYC non-amplified cell line. Moreover, the baseline expression of c-Myc was much lower than L-Myc in H209 cells. Two passages after G418 selection, c-Myc expression was observed in H209 cells (Figure 1a). Besides, we obtained that the overexpression of Myc

A)


B)

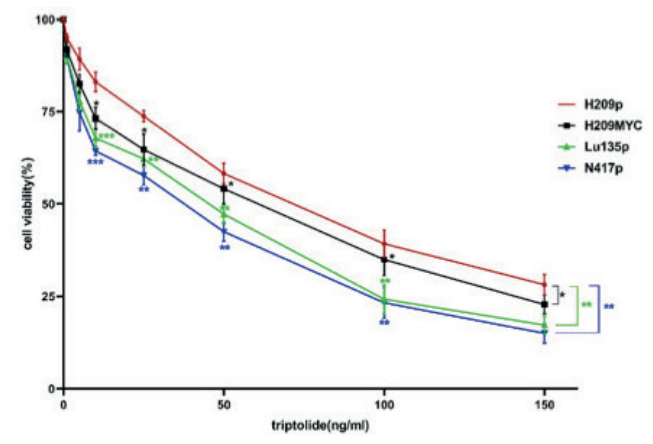

Figure 1. A) Overexpression of Myc induce cellular proliferation of $\mathrm{H} 209$ cells after lentiviral vector infection. B) Triptolide inhibit cellular proliferation of SCLC cells 
in $\mathrm{H} 209$ myc cells promotes cellular proliferation compared to H209 cells (Fig. 1a).

Triptolide inhibited the proliferation of SCLC cells through repressing $\mathrm{c}-\mathrm{Myc}$ expression

For the detection of possible cytotoxic activity of triptolide, H209, H209Myc, Lu135 and N417 cell lines treated with different concentrations of triptolide $(0,1,5,10,25,50,100$ and $150 \mathrm{ng} / \mathrm{ml})$ for $72 \mathrm{hrs}$. Dose and time-dependent response to Triptolide was evaluated. Figure $1 \mathrm{~b}$ indicates that Triptolide had cytotoxic effects on the cellular proliferation of SCLC cells.

We also calculated IC50 values for Triptolide (72hrs) and represented them in Table 1. Depending on IC values, we observed that $\mathrm{H} 209$ myc cells were more sensitive to Triptolide than H209 cells.

Table 1. IC50 values were estimated after $72 \mathrm{~h}$ treatment with Triptolide

\begin{tabular}{|c|c|}
\hline & IC50 Value $(\mathbf{n g} / \mathbf{m l})$ \\
\hline H209 & 67,59 \\
\hline H209myc & 47,86 \\
\hline Lu135 & 31,69 \\
\hline N417 & 25,83 \\
\hline
\end{tabular}

Depending on IC values, we observed that H209myc cells were more sensitive to Triptolide than H209 cells. Furthermore, considering the Myc expression status of SCLC cells, we concluded that Triptolide induced the inhibition of cell proliferation of SCLC cells in a Myc-dependent manner. To investigate whether this decrease in cell proliferation was caused by Myc reduction, western blot analysis was performed $48 \mathrm{~h}$ after triptolide treatment. Western blot analysis results showed that Myc expression was significantly decreased after triptolide treatment on H209Myc, Lu135, and N417 cell lines (Figure 2a). Gel band intensities were quantified by the Image J program (Figure $2 b$ ).

Triptolide represses cellular proliferation by regulating cell cycle regulatory molecules

Since growth suppression was observed upon triptolide treatment in SCLC cells, we evaluated the expressions of cell cycle regulator molecules after triptolide treatment by western blotting (p21, cyclin
A)

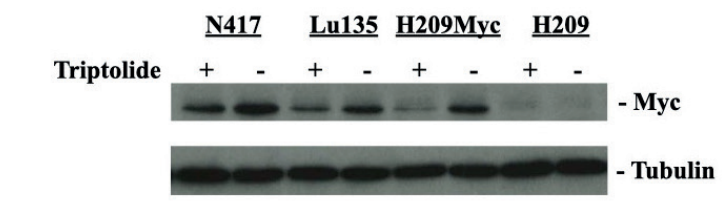

B)

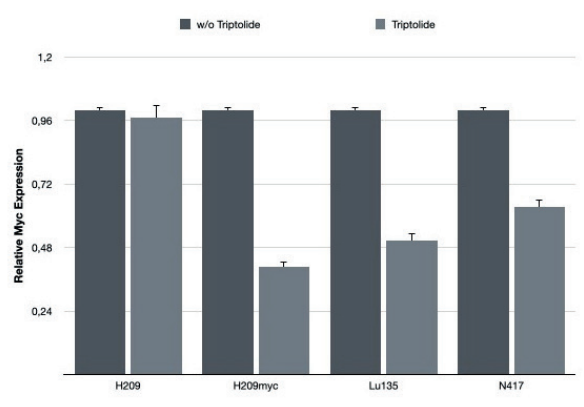

Figure 2. A) Effects of triptolide treatment on Myc protein levels. B) Band intensity of Myc protein

D1) (Figure 3a) and qRT-PCR (Myc, p21, Cyclin D1, CDK6, PTEN) (Figure 3b).

Because N417 cells are PTEN deficient, we did not check PTEN expression. Depending on qRT-PCR and western blot analysis results, c-Myc expression was significantly decreased after triptolide treatment. Additionally, we obtained that the triptolide treatment suppressed CDK6 and Cyclin D1 and overexpressed p21 and PTEN. So, reduced expressions of cell cycle activators and increased cell cycle inhibitors'

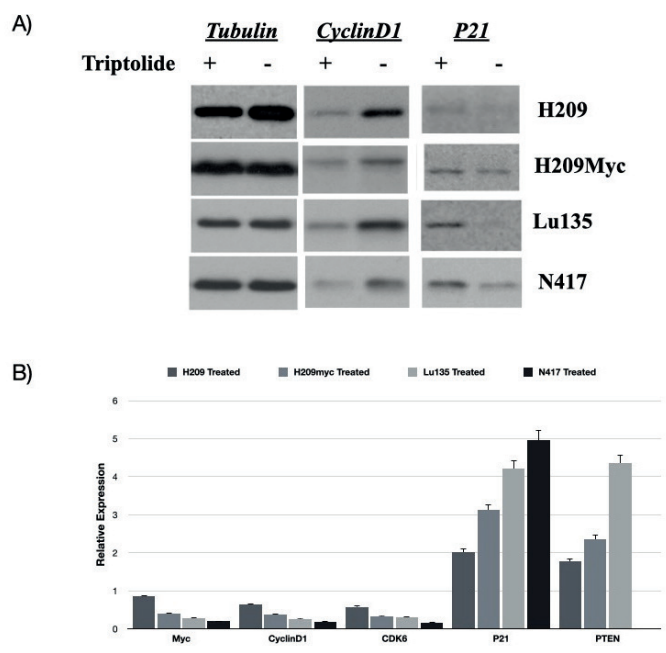

Figure 3. A) Triptolide treatment regulates p 21 and cyclinD1 protein levels. B) Triptolide repressed cellular proliferation via regulating cell cycle regulatory genes 
expression probably contribute to Triptolide's antiproliferative effects on SCLC cells.

\section{Triptolide suppresses glucose metabolism and} glucose uptake

Triptolide's mechanism-induced decrease of glucose consumption in SCLC cells was investigated using a Glucose Uptake-Glo ${ }^{\text {Tx }}$ Assay kit. Glucose uptake assay results indicated that glucose consumption was reduced after triptolide treatment (Figure 4a). Next, we evaluated glucose metabolism expressions related to genes in Triptolide-treated SCLC cells by using qRT-PCR analysis. Depending on PCR results, we obtained the decreased expressions of Glut1, Glut4, HK2, LDHA, and Eno1 (Figure 4b).

These results pointed out that Triptolide regulates glucose metabolism by repressing c-MYC expression in SCLC.
Triptolide treatment changes the expressions of cellular proliferation and metabolism-related IncRNAs

To check expression changes of lncRNAs after triptolide treatment, we performed qRT-PCR analysis for ANRIL, PVT1, PTENP1, H19, and lincRNA-p21. Our results demonstrated that Triptolide affected the expression levels of lncRNAs that have roles in proliferation (PTENP1 and LincRNA-p21) and cellular metabolism (ANRIL, PVT1, PTENP1, H19), as shown in Figure 5. Because N417 cells are PTEN deficient, we did not check PTENP1 expression.

Our previous manuscript explored the expression status of ANRIL, PVT1, PTENP1, H19, and lincRNAp21changes depending on Myc expression status. Similarly, in this study, we obtained that triptolide treatment can suppress Myc expression, and this suppression regulates the expressions of ANRIL,

A)

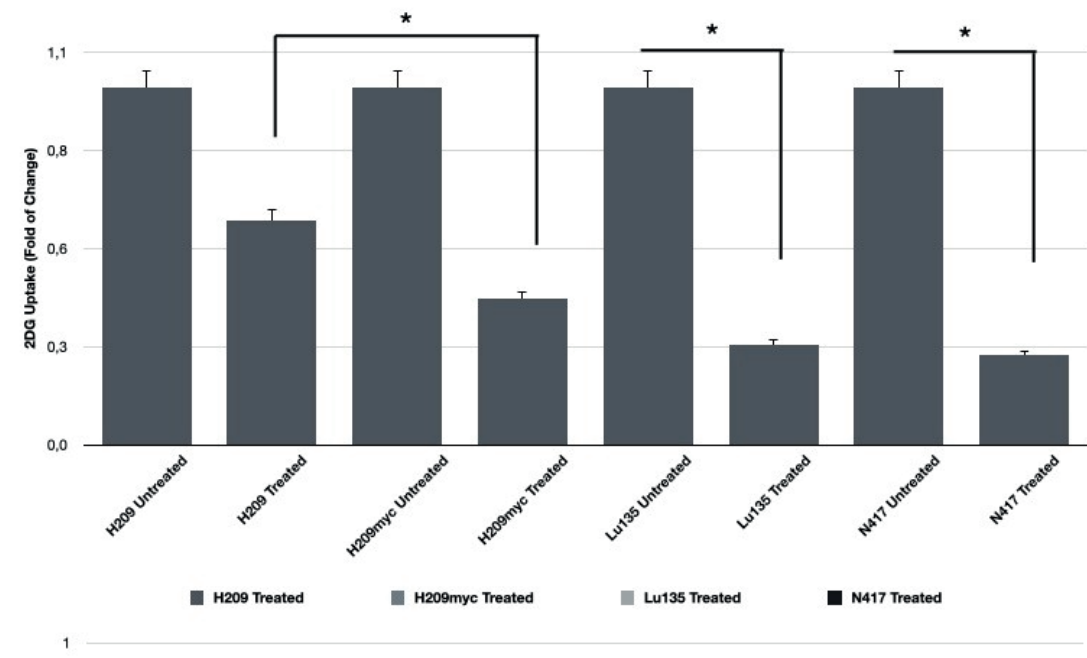

B)



Figure 4. A) 2-DG uptake in triptolide-treated SCLC cells. B) Triptolide treatment regulates glucose metabolism-related gene expression levels. 


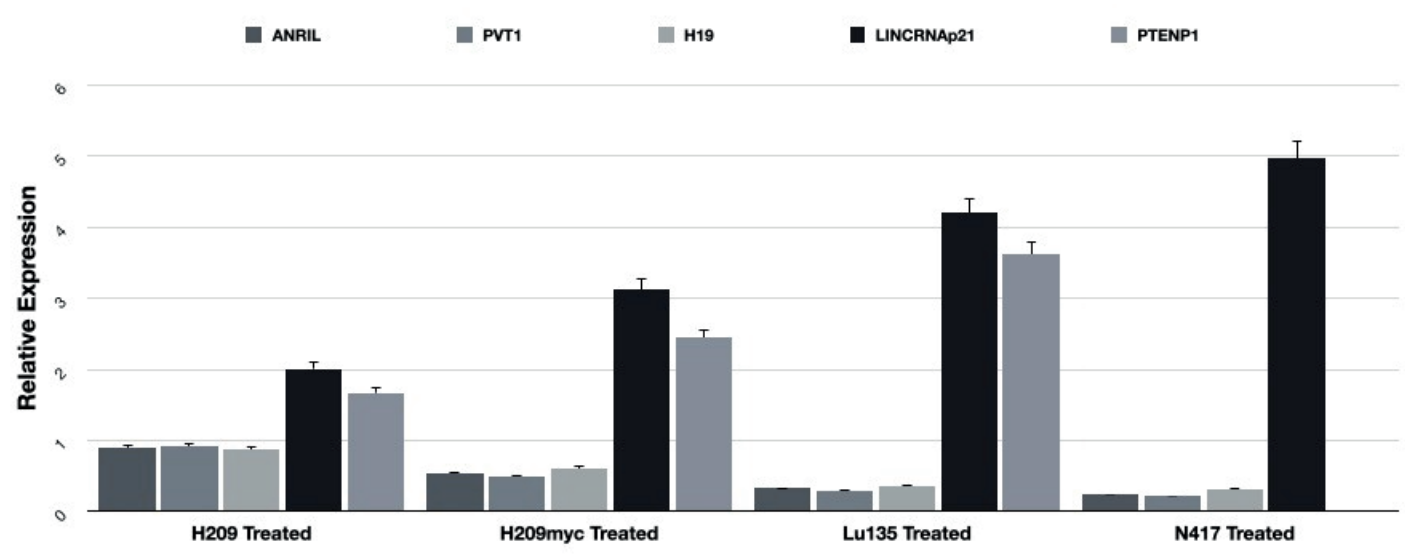

Figure 5. LncRNA expression changes depending on triptolide treatment

PVT1, PTENP1, H19, and lincRNA-p21. As a result of lncRNA expression experiments, triptolide treatment inhibited cellular proliferation by regulating Myc-dependent lncRNAs that play cellular proliferation and glucose metabolism roles.

\section{DISCUSSION}

Small cell lung cancer is a subtype of lung cancer that accounts for approximately $15 \%$ of lung cancer and has unique genomic features (2). Many clinical studies indicated that SCLC displays distinct characteristics, including extreme genomic instability, genetically amplified and/overexpressed different transcription factors, and poor prognosis $(3,4)$. Moreover, current diagnostic strategies for early detection and standard treatment protocols are insufficient to increase patients' overall survival. Consequently, the 5-year survival of patients is much less than $10 \%(13,14)$. Therefore, there is a need for new effective molecules that also have low cytotoxicity for patients. In the literature, studies have shown that Myc is the oncogenic driver in SCLC, and genetic aberrations in Myc have been identified to change different cellular mechanisms as particularly metabolism, in SCLC (17). Therefore, we believe that targeting Myc might be a significant therapeutic strategy for SCLC.

Triptolide, a natural product, has been investigated as a new agent for treating a broad range of cancers. Triptolide has been demonstrated to exert anti-tumor effects by reducing proliferation and inducing apoptosis in different cancer types, including cholangiocarcinoma, hepatocellular carcinoma, pancreatic cancer, and non-small cell lung cancer. Many studies to date have shown that Triptolide can inhibit various human solid tumors in vivo and in vitro. It is also known that this inhibitory effect is achieved by affecting multiple mechanisms, especially inhibitory heat shock factor-1 (HSF-1), suppression of DNA damage response, and regulating mRNA stability. Although Triptolide's anticancer property has been shown in the literature with some studies in lung cancers, there is no study showing its effect on small cell lung cancer. Studies are showing the effect of Triptolide on MYC expression in various cancer types. Therefore, we have foreseen that Triptolide might be an effective anticancer molecule in small cell lung cancers where Myc overexpression or amplification is observed at a rate of $15 \%$. Hence, in this study, we examined Triptolide's effect on SCLC cell lines with or without Myc overexpression. Previous studies have shown that Triptolide can downregulate the expression of c-Myc in non-small cell lung carcinoma (7). Correlatively, our study revealed that Triptolide decreased the expression of Myc in SCLC cell lines.

Furthermore, we observed that when we treated the Triptolide cells, H209myc cells were more sensitive than $\mathrm{H} 209$ parental cells. These results indicated that SCLC cells are more addicted to MYC for their growth and survival than the cells without MYC amplification and/or overexpression. Therefore, they are susceptible to MYC inhibition by triptolide treatment. Moreover, we have shown that Triptolide repressed cellular proliferation via regulating cell cycle regulatory genes, 
which Myc regulates. The literature indicates that cell cycle regulatory genes like cyclin D1 and CDK6 are a transcriptional target of Myc (14). In this study, we also found that expressions of cell cycle regulatory genes like cyclin D1 and CDK6 were significantly decreased with Myc in SCLC cells. Conversely, triptolide treatment increased the expressions of PTEN and $\mathrm{p} 21$. These data strengthen the evidence that triptolide treatment represents a common inhibitor for the MYC protein in vitro and further supports Triptolide's utility as a therapeutic strategy for SCLC.

Cellular metabolism and proliferation are closely linked to cellular processes. MYC oncogene has a critical role in the regulation of aerobic glycolysis. MYC transcriptionally regulates almost all glycolytic genes by binding the E-box sequence (12). We analyzed the expression changes of glucose metabolism-related genes after triptolide treatment in light of this information. Our results indicated that triptolide treatment decreased the expression of glucose metabolism-related genes. These results support the inhibition of glucose metabolism and repression of cellular proliferation in SCLC cells by triptolide treatment.

Many experimental studies have revealed that long-noncoding RNAs (lncRNAs) have a role in regulating cancer cell metabolism. Different lncRNAs have pivotal roles in metabolic reprogramming of various cancer types such as non-small cell lung cancer (lncRNA-NEF), hepatocellular carcinoma (lncRNA Ftx, HOTAIR, TUG1, LINC01554), osteosarcoma (TUG1, PVT1), ovarian cancer (SNHG3), gastric cancer(MACC1-AS1)(26). Increasing pieces of evidence have shown that lncRNAs regulate essential genes in glucose metabolism. Our previous studies indicated that Myc regulates various $\ln$ RNAs in SCLC and breast cancer $(14,16)$. The present results demonstrated that triptolide treatment could regulate cellular proliferation and glucose metabolism via Mycregulated lncRNAs (ANRIL, PVT1, PTENP1, H19, and lincRNA-p21) in SCLC.

\section{CONCLUSION}

In summary, we demonstrated the promising use of Myc as a target for SCLC therapy by using Triptolide of its expression. The results have strongly indicated that triptolide treatment reduces cellular proliferation and glucose metabolism by regulating lncRNA expressions. Accordingly, it was concluded from this study that triptolide treatment would be a promising therapeutic strategy for SCLC.

Hakem Değerlendirmesi: Dış bağımsız.

Peer Review: Externally peer-reviewed.

Yazar Katkıları: Çalışma Konsepti/Tasarım- O.T.; Veri Toplama- O.T., K.İ.; Veri Analizi/YorumlamaO.T., K.İ.; Yazı Taslağı- O.T., K.İ.; İçeriğin Eleştirel İncelemesi- O.T.; Son Onay ve Sorumluluk- O.T., K.İ.

Author Contributions: Conception/Design of Study- O.T.; Data Acquisition- O.T., K.İ.; Data Analysis/Interpretation- O.T., K.İ.; Drafting Manuscript- O.T., K.İ.; Critical Revision of Manuscript- O.T.; Final Approval and AccountabilityO.T., K.İ.

Çıkar Çatışması: Yazarlar çıkar çatışması beyan etmemişlerdir

Conflict of Interest: Authors declared no conflict of interest.

Finansal Destek: Yazarlar finansal destek beyan etmemişlerdir.

Financial Disclosure: Authors declared no financial support.

\section{REFERENCES}

1. Santarpia M, Daffinà $M G$, Karachaliou N, González-Cao M, Lazzari C, Altavilla G, et al. Targeted drugs in small-cell lung cancer. Transl Lung Cancer Res 2016;5(1):51-70.

2. Gazdar AF, Bunn PA, Minna JD. Small-cell lung cancer: what we know, what we need to know, and the path forward. Nat Rev Cancer 2017;10:17(12):765.

3. Deneka AY, Boumber Y, Beck T, Golemis EA. Tumor-Targeted Drug Conjugates as an Emerging Novel Therapeutic Approach in Small Cell Lung Cancer (SCLC). Cancers (Basel) 2019;11(9):1297.

4. Codony-Servat J, Verlicchi A, Rosell R. Cancer stem cells in small cell lung cancer. Transl Lung Cancer Res 2016;5(1):16-25.

5. Taniguchi H, Sen T, Rudin CM. Targeted Therapies and Biomarkers in Small Cell Lung 
Cancer. Front Oncol 2020;10:741.

6. Zhang W, Girard L, Zhang YA, Haruki T, Papari-Zareei M, Stastny V, et al. Small cell lung cancer tumors and preclinical models display heterogeneity of neuroendocrine phenotypes. Transl Lung Cancer Res 2018;7(1):32-49.

7. Lüscher B, Vervoorts J. Regulation of gene transcription by the oncoprotein MYC. Gene 2012;494(2):145-60.

8. Kress TR, Sabò A, Amati B. MYC: connecting selective transcriptional control to global RNA production. Nat Rev Cancer 2015;(10):593-607.

9. Mollaoglu G, Guthrie MR, Böhm S, Brägelmann J, Can I, Ballieu PM et al. MYC Drives Progression of Small Cell Lung Cancer to a Variant Neuroendocrine Subtype with Vulnerability to Aurora Kinase Inhibition. Cancer Cell 2017;31(2):270-85.

10. García-Gutiérrez L, Bretones G, Molina E, Arechaga I, Symonds C, Acosta JC et al. Myc stimulates cell cycle progression through the activation of Cdk1 and phosphorylation of p27. Sci Rep 2019;9(1):18693.

11. Schwinkendorf D, Gallant P. The conserved Myc box 2 and Myc box 3 regions are important, but not essential, for Myc function in vivo. Gene 2009;436(1-2): 90-100.

12. Miller DM, Thomas SD, Islam A, Muench D, Sedoris K. c-Myc and cancer metabolism. Clin Cancer Res 2012;18(20):5546-53.

13. Tokgun O, Tokgun PE, Inci K, Akca H. lncRNAs as Potential Targets in Small Cell Lung Cancer: MYC -dependent Regulation. Anticancer Agents Med Chem. 2020;20(17):2074-81.

14. Kim JW, Zeller KI, Wang Y, Jegga AG, Aronow BJ, O'Donnell KA, et al. Evaluation of myc E-box phylogenetic footprints in glycolytic genes by chromatin immunoprecipitation assays. Mol Cell Biol 2004;24(13):5923-36.

15. Huarte M. The emerging role of lncRNAs in cancer. Nat Med 2015;21:1253-61.

16. Tokgun PE, Tokgun O, Kurt S. MYC-driven regulation of long non-coding RNA profiles in breast cancer cells. Gene 2019;25 (714):143955.
17. Dong Y, Tu R, Liu H. Regulation of cancer cell metabolism: oncogenic MYC in the driver's seat. Sig Transduct Target Ther 2020;5(1):124.

18. Dang CV. Therapeutic targeting of Mycreprogrammed cancer cell metabolism. Cold Spring Harb Symp Quant Biol 2011;76:369-74.

19. Kato F, Fiorentino FP, Alibés A, Perucho M, Sánchez-Céspedes M, Kohno T et al. MYCL is a target of a BET bromodomain inhibitor, JQ1, on growth suppression efficacy in small cell lung cancer cells. Oncotarget. 2016;7(47):77378-88.

20. Fiorentino FP, Tokgün E, Solé-Sánchez S, Giampaolo S, Tokgün O, Jauset T, Kohno T et al. Growth suppression by MYC inhibition in small cell lung cancer cells with TP53 and RB1 inactivation. Oncotarget 2016;7(21):31014-28.

21. Noel P, Von Hoff DD, Saluja AK, Velagapudi M, Borazanci E, Han H. Triptolide and Its Derivatives as Cancer Therapies. Trends Pharmacol Sci 2019;40(5):327-41.

22. Zhu J, Wang H, Chen F, Lv H, Xu Z, Fu J et al. Triptolide enhances chemotherapeutic efficacy of antitumor drugs in non-small-cell lung cancer cells by inhibiting Nrf2-ARE activity. Toxicol Appl Pharmacol 2018;358:1-9.

23. Chen SR, Dai Y, Zhao J, Lin L, Wang Y, Wang Y. A Mechanistic Overview of Triptolide and Celastrol, Natural Products from Tripterygium wilfordii Hook F. Front Pharmacol 2018;9:104.

24. Kong J, Wang L, Ren L, Yan Y, Cheng Y, Huang $\mathrm{Z}$ et al. Triptolide induces mitochondriamediated apoptosis of Burkitt's lymphoma cell via deacetylation of GSK-3 $\beta$ by increased SIRT3 expression. Toxicol Appl Pharmacol 2018;342:113.

25. Carney DN, Gazdar AF, Bepler G, Guccion JG, Marangos PJ, Moody TW et al. Establishment and identification of small cell lung cancer cell lines having classic and variant features. Cancer Res 1985;45(6):2913-23.

26. Lu W, Cao F, Wang S, Sheng X, Ma J. LncRNAs: The Regulator of Glucose and Lipid Metabolism in Tumor Cells. Front Oncol 2019;9:1099. 
